\title{
Библиотека као радионица и инспирација
}

\author{
Берислав Благојевић \\ berislav.blagojevic@nub.rs \\ Марија Павловић \\ marija.pavlovic@nub.rs \\ Народна и универзитетска библиотека Републике Српске, Бања Лука
}

\begin{abstract}
Сажетак
Рад се бави односима и везама између књижевника, књижевности и библиотеке, при чему библиотеку одликује двојака улога - радионице и инспирације. Библиотека као радионица посматра се као мјесто које нуди информације и неопходну грађу за настајање књижевног дјела, али и као физички простор у коме књижевност настаје. Библиотека у контексту извора инспирације за књижевнике сагледана је из неколико аспеката, уз приједлог могућих начина даљег проучавања. У раду се анализира у којој мјери и на који начин се преплићу наука и умјетност, библиотекарство и књижевност, а посебна пажња рада посвећена је заступљености библиотеке као теме, мотива и инспирације у дјелима писаца. Такође, предмет анализе је утицај библиотеке као радионице и инспирације на савремено стваралаштво писаца и књижевникабиблиотекара у Србији и Републици Српској.
\end{abstract}

Кључне ријечи: библиотека, књижевност, српска књижевност, библиотекарство, инспирација, радионица, писцибиблиотекари, читање, информација, грађа, књижевно дјело

\section{Уводна разматрања}

Однос библиотеке и књижевности изузетно је комплексан и могуће га је сагледати кроз разноврсне окуларе. 3бог тога и приступи изучавању овог односа могу да буду различити: кроз призму теорије и праксе у библиотекарству, културолошки, антрополошки, социолошки, комуниколошки, са аспекта информационих теорија и др. У зависности да ли се говори о јавној или приватној библиотеци, о библиотеци као извору информација и грађе неопходних за настанак књижевног дјела, о библиотеци као простору у којем се ствара, или простору који је надахнуће за чин креативног стварања, испреплетеност веза и утицаја је фасцинантна. Сложеност ових утицаја, на примјер, може да се уочи приликом анализе дјела која обрађују тему библиотеке, а која је условно могуће подијелити на пет подгрупа - филозофска проза, дјела социјалнопсихолошке тематике и тематике свакидашњег живота, фантастични романи и приповијетке, детективска књижевност и романи страве и ужаса. ${ }^{1}$ Међутим, овај рад фокусиран је на један значајан и издвојен сегмент поменутих веза и односа који подразумијева посматрање библиотеке као радионице (мјеста у којем се ствара или у којем се прикупља грађа) и библиотеке као инспирације.

Основу теоријског оквира за сагледавање двојаке функције библиотеке као радионице и инспирације представља шири контекст односа у троуглу писац - библиотека - читање. У центру овог троугла налазе се информације, односно комуникација. Премда су улоге књижевника и библиотеке у овом смислу наизглед недвосмислене, потребно је нагласити да се библиотека, било јавна или приватна, овдје доживљава као физички простор у коме се ствара, али и као

\footnotetext{
${ }^{1}$ Михаил Јурјевич Матвејев, „Моћ стереотипа или разноврсност приступа?”, у Библиоеиека као оїлеgало васионе: оїлеgи из савремене руске науке о библиошеккарсииву, изабрао, приредио и превео Добрило Аранитовић, уредник издања Милојко Кнежевић (Београд: ІП Службени гласник; Инђија: Народна библиотека „Др Ђорђе Натошевић”, 2009), 109-118.
} 
извор информација и надахнућа, те као метафора или симбол у самом умјетничком дјелу. Поменута дуална функција библиотеке у нераскидивој је вези с књижевником који у овом концепту такође може имати више улога: као аутор који је уједно и библиотекар, као неко коме библиотека служи као инспирација за књижевно дјело, као особа која потребне информације за списатељски чин проналази у библиотеци, или као аутор који тај списатељски чин спроводи у библиотечком окружењу.

Посебно је важно разјаснити на шта се мисли у контексту читања и информације. Овдје се под читањем, које се природно везује за библиотеке, књиге и писце, мисли на активно, дубинско, истраживачко читање. То је читање с оловком у руци, јер је, како рече Андрић „читати без бележака исто што и читати на једно око". ${ }^{2}$ Овакво читање доводи до дискусије с текстом и потиче на стварање новог књижевноумјетничког дјела, или на писање есеја, књижевне критике и сл. Александар Генис подржава овакву врсту читања, истичући да је читање с оловком у руци обавезно. Управо због тога предност даје личним библиотекама, јер „књига мора бити твоја: туђу треба вратити и срамота је прљати је. Белешку обичне оловке, наравно, могуће је обрисати гумицом, али то нипошто не треба радити. Библиотеку не треба поседовати, њоме се треба служити, колико год њу то коштало". ${ }^{3}$

О сродности и повезаности библиотека и информација написано је много, али суштина се огледа у сљедећем: „Библиотеке су места на која људи иду због информација. Књиге су само врх тог леденог брега". ${ }^{4}$ Доиста, некњижна библиотечка грађа може књижевницима да пружи информације од непроцјењиве важности за настанак књижевног дјела. У недостатку статистичких података о томе у којој мјери се књижевници служе библиотеком као извором информација за потребе стварања књижевног дјела и у којој мјери се процес писања одвија у физичком простору библиотеке, методолошки оквир не може да се ослони на математичко-статистички аспект. Историјски метод није доминантан и у раду је парцијално присутан, првенствено у контексту увида у рад писаца-библиотекара у прошлости. Због тога се теоријско-методолошка основа углавном ослања на аналитички метод кроз увид у садржај самих књижевних дјела или опуса појединих аутора, узимајући у обзир и чињенице о томе да ли је аутор истовремено и библиотекар или није.

Приликом поимања библиотеке као радионице и инспирације, дакле, могуће је дефинисати неколико основних веза и односа између библиотеке и књижевности, односно писаца и библиотеке:

- писци који нису библиотекари, али пишу о библиотекама;

- писци-библиотекари који пишу у библиотеци;

- писци-библиотекари који пишу о библиотекама.

Поред наведених појавних облика могући су и разни варијетети, али овај рад ће се задржати на анализи ова три у оквиру којих ће посебна пажња бити посвећена стваралаштву савремених књижевника и писаца-библиотекара у Републици Српској и Србији.

\section{Библнотека као радионица}

Историја библиотека показује да је традиција библиотекарске професије од давнина у нераскидивој вези с бројним књижевницима и научницима. ${ }^{5}$ Анхел Естебан је прије неколико година у књизи Писаи, у свом рају издвојио тридесет великих књижевника који су били библиотекари, обухватајући период од 16. вијека до данашњих дана. Увидом у животописе представљене у овој

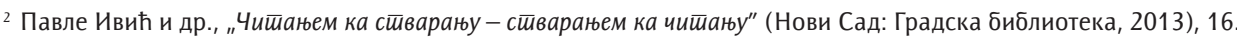

${ }^{3}$ Александар Генис, Часови иитиања, камасуйра заљубљеника у књиіуу (Београд: Геопоетика, 2015), 98.

${ }^{4}$ Нил Гејмен, „Зашто наша будућност зависи од библиотека, читања и сањарења (2)”, Країујевачко чишалишйе бр. 38 (децембар 2014): 22-25.

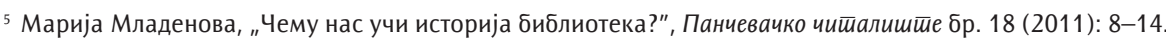


књизи, може се закључити да је значајан број оних писаца-библиотекара који су користили радно мјесто у библиотеци за потребе властитог стваралаштва, било да се ради о доступности књижног фонда, бољем приступу грађи за потребе истраживања, или о физичком простору библиотеке који пружа најоптималније услове за рад. У том смислу, за све ове ауторе библиотека представља радионицу, амбијент у коме се ствара и незамјењив извор грађе и информација. Роберт Бартон, на примјер, био је оксфордски библиотекар и писац чији су извори били изразито књижевни и књишки. Истраживачким радом у бројним библиотекама (у некима од њих били су и запослени) за потребе свог рада бавили су се и браћа Грим. Марио Варгас Љоса истиче како је добар дио свога дјела написао у библиотекама или баровима. Гете је повремено у библиотеци налазио тренутке мира како би in situ обављао свој књижевни рад, а познато је да је Борхес у библиотеци написао неке од најбољих прича: „Лутрија у Вавилону”, „Смрт и бусола”, „Orbis Tertius”. 6

Ипак, без обзира на ове илустративне примјере, веома је тешко без конкретних података и (ауто)биографских увида утврдити у којој мјери књижевници-библиотекари стварају у окружју библиотеке. Могуће је, међутим, кроз њихова дјела открити трагове или чак јасне доказе истраживања, конкретне теме, наслове или ауторе којима се често, такорећи опсесивно, враћају. Анализирајући рад неких библиотекара-писаца, долази се до закључка да су њихова дјела у одређеној мјери зачеци засебних малих библиотека или пак библиотечких цјелина. Ови писци-библиотекари су у могућности да у оквиру библиотеке-радионице користе грађу и доступне информације како би приређивачким, есејистичким или критичарским радом скренули пажњу на неке мање познате чињенице или на скрајнуте књижевнике и њихова дјела. У овом процесу, библиотека као радионица даје неопходне идеје, грађу и информације, а заузврат бива обогаћена новим сазнањима, синтезама, раније необјављеним рукописима и др. Као примјер можемо да наведемо вишеструки ангажман Мирка Демића у скретању пажње на дјела Милана Будисављевића, Милана Прибићевића, Ника Бартуловића, Милке Жицине, Станислава Кракова, Владана Деснице, Ђорђа А. Петровића, Слободана Павићевића... ${ }^{7}$ Наш познати књижевник и директор Народне библиотеке „Вук Караџић” у Крагујевцу на овај начин као да ствара једну надасве особену библиотеку, колико интимну и личну, толико и јавну. Слично, премда у знатно мањем обиму, Предраг Лазаревић, некадашњи управник Народне библиотеке „Петар Кочић” у Бања Луци, дао је допринос завичајној збирци пошто је приредио књиге скрајнутих и готово заборављених аутора као што су Миле Бекут и Владо Дијак. ${ }^{8}$ У овом контексту може се поменути и Бела Хамваш који је посао библиотекара обављао од 1927. до 1948. године у Сечењи Националној библиотеци Мађарске у Будимпешти. ${ }^{9}$ Нема никакве сумње да је за његово знање и импозантан опус барем дјелимично заслужан управо посао у библиотеци. Свједочећи разарањима у Другом свјетском рату, Хамваш 1945. осмишљава издавачки пројекат Сш̄о књиїа као идеју да је, уколико би све друге књиге нестале, само на основу тих књига могуће успоставити књижевну линију човјечанства. ${ }^{10}$ Овај пројекат може се посматрати и као стварање својеврсне библиотеке - библиотеке Судњег дана.

Ови примјери указују како се под синтагмом библиошека као раgионииа не мора нужно мислити на конкретан списатељски рад у одређеном физичком простору, јер су код библиотекара-књижевника читање, истраживање, писање и библиотекарство испреплетени на доиста специфичан начин. Међутим, како првобитно и најочигледније схватање библиотеке као радионице претпоставља одговарајући простор под окриљем ове установе у коме се ствара, треба истаћи да неке библиотеке посједују такве намјенске просторије. Као један од многобројних

\footnotetext{
${ }^{6}$ Anhel Esteban, Pisac u svom raju. Trideset velikih pisaca koji su bili bibliotekari (Beograd: Dereta, 2016).

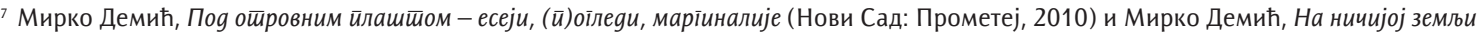
- есеји, маріиналије и јеgан йуйойис (Нови Сад: Solaris, 2016).

8 Данка Делић, Библиоірафија Преgраїа Лазаревића (Бања Лука: Универзитет у Бањој Луци, Филолошки факултет, 2011).

${ }^{9}$ Széchényi-Nationalbibliothek (Országos Széchényi Könyvtár), http://www.wikiwand.com/en/National_Sz\%C3\%A9ch\%C3\%A9nyi_ Library\# (preuzeto 16. 7. 2017).

${ }^{10}$ Бела Хамваш, Сйо књиїа (Београд: Тардис, 2011).
} 
примјера можемо навести The Writers' Room у оквиру Toronto Reference Library која је намијењена искључиво књижевницима. Ова „соба за писце” обухвата четири засебна радна простора, приступ интернету, фондовима библиотеке, а за потребе истраживања, књижевницима стручну помоћ пружају библиотекари. ${ }^{11}$ Наравно, библиотека као радионица се овдје не исцрпљује, јер преостаје да се истражи и делање у оквиру приватних, односно, кућних библиотека.

\section{Библиотека као инспирација}

Премда је, као што је приказано, библиотека била и још јесте мјесто у коме се ствара, она је списатељима много чешће инспирација. У задатим појмовно-теоријским оквирима, може се говорити о библиотеци као инспирацији за писце-библиотекаре, те за писце који нису библиотекари. Могуће је издвојити ауторе у чијем опусу библиотека као инспирација заузима значајно мјесто, књижевнике чије су комплетне рукописне цјелине (циклуси пјесама, приповједачке збирке или романи) инспирисане библиотеком, те оне који су у свом креативном раду били фрагментарно посвећени библиотекама и библиотекарству. Важно је истаћи и писце који су у одређеним текстовима (у дневним новинама, стручним или књижевним периодичним публикацијама и др) афирмативно писали или говорили о библиотекама и њиховом значају. ${ }^{12}$ Такође, могуће је извршити и детаљну подјелу према којој је библиотека инспирација за дјела у којима се радња одвија у њој, или она у којима је библиотекар/ка главни јунак, или пак дјела гдје се библиотека третира као мит, симбол и слично. Поред ових, присутна су и дјела умјетничке књижевности која се баве непосредним проблемима библиотекарства, као на примјер роман Бурияанов маїараи, Гинтера де Бројна. ${ }^{13}$

Упркос постојању многобројних аналитичких приступа у проучавању библиотеке као инспирације, у фокусу овог рада је савремено стваралаштво књижевника и писаца-библиотекара у Републици Српској и Србији. Од аутора којима је библиотека била инспирација за цјелокупне књиге, издвајају се, на примјер, Зоран Живковић и његово дјело Библиошека, ${ }^{14}$ те Ранко Павловић са збирком приповједака Библиошекар и Књиї. ${ }^{15}$ У обје књиге се тематике књига, читања, писања и библиотека обрађују на занимљиве начине, показујући ширину коју пружа библиотека као инспирација. Појединачних прича или пјесама инспирисаних библиотеком у нашој књижевности има релативно много. Антологијски избор прича Зона библиона који је приредио Миленко Стојичић, а објавила Народна и универзитетска библиотека Републике Српске веома добро илуструје прозно богатство инспирисано и посвећено библиотекама - од Иве Андрића, Бранка Ћопића, Милорада Павића и Данила Киша, преко Давида Албахарија, Горана Петровића, до Јелене Ленголд, Лауре Барне и многих других. У овом избору нашле су се и приче неколицине аутора из Републике Српске (Слободан Бошковић, Радо Димитријевић, Ранко Павловић), али и библиотекара-писаца као што су Мирко Демић и Ранко Рисојевић. ${ }^{16}$ И коаутор овог рада припада књижевницима-библиотекарима из Републике Српске који су често у прозним дјелима писали о библиотекама. ${ }^{17}$ Библиотека се у савременом стваралаштву често јавља у форми есеја, маргиналија и кратких прозних цртица, као што је то случај са текстом „Библиотека” у

\footnotetext{
11 Toronto Public Library, The Writers Room, http://www.torontopubliclibrary.ca/services/the-writers-room.jsp (preuzeto 18. 7. 2017).

12 Давид Албахари, „Кућна библиотека расте са својим власником”, Країујевачко иишалишеше бр. 36 (2014): 11-12 и Васа Павковић, „Моја библиотека, моја аутобиографија", Країујевачко иишалишие бр. 36 (2014): 13-14.

13 Гинтер де Бројн, Бурияанов маїараи (Београд: Фабрика књига, 2007).

${ }^{14}$ Zoran Živković, Biblioteka (Beograd: Everest medija, 2008).

15 Ранко Павловић, Библиойекар и књиїа (Источно Сарајево: Завод за уџбенике и наставна средства, 2006).

${ }^{16}$ Миленко Стојичић, Зона библиона-аншеолоїја ирииа о библиошекама (Бања Лука: Народна и универзитетска библиотека Републике Српске, 2013)

17 Берислав Благојевић, „Сусрет”, Књижевник бр. 25/26 (2010): 100-104; Берислав Благојевић, „Викенд са грофом Марсиљијем”, Кваршал бр. 22/23 (пролеће/лето 2014): 22-23; Berislav Blagojević, Bumerang (Mladenovac: Presing, 2016)
} 
књизи Љубавна йисма и gруїе лекције Милисава Савића. ${ }^{18}$ Као мотив, библиотека је присутна и у савременој поезији аутора из Републике Српске. Александра Чворовић, списатељица-библиотекарка из Бања Луке, у пјесми „Постоји ли читалац" из збирке Наgрасшање пише: „Има ли га / Иза седам гора / Иза седам мора / У деветом кругу најдубље библиотеке / У недођији књижевног раја...". ${ }^{19}$ Жељко Ђурђевић у поетској књизи Изнајмљена шиуина има сљедеће стихове: „На раскршћу поезије у прозу / са погледом на београдске библиотеке пуне књига / које се краду читањем и односе далеко у свијет...". ${ }^{20}$ Татјана Бијелић, пјесникиња из Бања Луке, уврстила је у збирку Два йушиа из Оксфорgа пјесму под насловом „Десерт у библиотеци". ${ }^{21}$

Наведени књижевници и писци-библиотекари представљају мањи избор оних којима је библиотека послужила као инспирација. Важно је додати и то да је посебна пажња посвећена писцима из Републике Српске, али да је и овај преглед тек полазиште за нека будућа истраживања у овом контексту.

\section{Закључак}

Предложеним теоријским оквиром, чије је исходиште у релацијама између библиотеке, писца, читања, грађе и информација, покушало се с пружањем увида у могућа разматрања идеје библиотеке као радионице и библиотеке као инспирације. У оквиру посматрања библиотеке као радионице, могуће је издвојити два битна елемента: библиотека је извор информација и грађе за настајање књижевног дјела, али уједно представља и простор у коме настаје књижевно дјело. На различитим примјерима кроз историју показани су утицаји окружења библиотеке на стваралаштво књижевника, нарочито писаца-библиотекара. Библиотека као инспирација првенствено је посматрана кроз призму писца - у зависности да ли је аутор уједно библиотекар или није. Потом је извршена и анализа својеврсне квантитативне улоге библиотеке као инспирације, при чему су дати примјери дјела у којима библиотека заузима централно мјесто, те она друга прозна и поетска остварења у којима се библиотека појављује фрагментарно. У контексту библиотеке као радионице и инспирације посебно су наглашена дјела савремених српских књижевника, уз апострофирање библиотекара-књижевника. У том смислу, дат је и преглед стваралаштва неких књижевника и писаца-библиотекара из Републике Српске као основа за нека будућа проучавања о преплитању сложених веза и односа између библиотеке, књижевности, креативног стваралачког процеса, читања и истраживања.

\section{Литература и извори:}

1. Albahari, David. „Kućna biblioteka raste sa svojim vlasnikom”. Kragujevačko čitalište br. 36 (2014): 11-12.

2. Bijelić, Tatjana. Dva puta iz Oksforda. Banja Luka; Beograd: Zadužbina Petar Kočić, 2009.

3. Blagojević, Berislav. „Susret”. Književnik br. 24/25 (2010): 100-104.

4. Blagojević, Berislav. „Vikend sa grofom Marsiljijem”. Kvartal br. 22/23 (proleće/leto 2014): 22-23.

5. Blagojević, Berislav. Bumerang. Mladenovac: Presing, 2016.

6. Čvorović, Aleksandra. Nadrastanje. Banja Luka: Udruženje književnika Srpske podružnica Banja Luka, Kuća poezije, 2013.

7. Brojn, Ginter de. Buridanov magarac. Beograd: Fabrika knjiga, 2007.

\footnotetext{
${ }^{18}$ Милисав Савић, Љубавна йисма и яруїе лекиије (Зрењанин: Агора, 2012), 71-73.

${ }^{19}$ Александра Чворовић, Наgрасшиае (Бања Лука: Удружење књижевника Српске подружница Бања Лука, Кућа поезије, 2013 ), 107.

20 Željko Đurđević, Iznajmljena tuđina (Banja Luka: Art print, 2013), 44.

21 Tatjana Bijelić, Dva puta iz Oksforda (Banja Luka; Beograd: Zadužbina Petar Kočić, 2009).
} 
8. Delić, Danka. Bibliografija Predraga Lazarevića. Banja Luka: Univerzitet u Banjoj Luci, Filološki fakultet, 2011.

9. Demić, Mirko. Pod otrovnim plaštom - eseji, (p)ogledi, marginalije. Novi Sad: Prometej, 2010.

10. Demić, Mirko. Na ničijoj zemlji - eseji, marginalije i jedan putopis. Novi Sad: Solaris, 2016.

11. Đurđević, Željko. Iznajmljena tuđina. Banja Luka: Art print, 2013.

12. Esteban, Anhel. Pisac u svom raju. Trideset velikih pisaca koji su bili bibliotekari. Beograd: Dereta, 2016.

13. Gejmen, Nil. „Zašto naša budućnost zavisi od biblioteka, čitanja i sanjarenja (2)”. Kragujevačko čitalište br. 38 (2014): 22-25.

14. Genis, Aleksandar. Časovi čitanja, kamasutra zaljubljenika u knjigu. Beograd: Geopoetika, 2015.

15. Hamvaš, Bela. Sto knjiga. Beograd: Tardis, 2011.

16. Ivić, Pavle, Olivera Gajić, Milanka Maljković i Sofija Košničar. Čitanjem ka stvaranju - stvaranjem ka čitanju. Novi Sad: Gradska biblioteka, 2013.

17. Matvejev, Mihail Jurjevič. „Moć stereotipa ili raznovrsnost pristupa?”. U Biblioteka kao ogledalo vasione: ogledi iz savremene ruske nauke o bibliotekarstvu. Izabrao, priredio i preveo Dobrilo Aranitović. Urednik izdanja Milojko Knežević, 109-118. Beograd: JP Službeni glasnik; Inđija: Narodna biblioteka „Dr Đorđe Natošević", 2009.

18. Mladenova, Marija. „Čemu nas uči istorija biblioteka?". Pančevačko čitalište br. 18 (2011): 8-14.

19. Pavković, Vasa. "Moja biblioteka, moja autobiografija”. Kragujevačko čitalište br. 36 (2014): 13-14. 20. Pavlović, Ranko. Bibliotekar i knjiga. Istočno Sarajevo: Zavod za udžbenike i nastavna sredstva, 2006. 21. Savić, Milisav. Ljubavna pisma i druge lekcije. Zrenjanin: Agora, 2012.

22. Stojičić, Milenko. Zona bibliona - antologija priča o bibliotekama. Banja Luka: Narodna i univerzitetska biblioteka Republike Srpske, 2013.

23. Toronto Public Library. The Writers Room. http://www.torontopubliclibrary.ca/services/the-writersroom.jsp (preuzeto 18. 7. 2017).

24. Živković, Zoran. Biblioteka. Beograd: Everest medija, 2008

\section{Library as a Workshop and Inspiration}

\section{Summary}

The paper deals with relations and connections between writers, literature and library, with the library appearing in a dual role - as a workshop and inspiration. As a workshop, the library is seen as a place that provides information and material for creating a literary work, but also as a physical space in which literature is being created. In the context of the source of inspiration for writers, the library is examined from several aspects, with the suggestion of possible ways of further studies. The paper analyzes the extent to which science and art, librarianship and literature interweave, and the special attention is paid to the presence of the library as a theme, motive and inspiration in the works of writers. An analysis of the quantitative role of the library as an inspiration was also made, with examples of the literary works in which the library occupies a central place, as well as the prose and poetic works in which it appears fragmentarily. Also, the subject of the analysis is the influence of the library as a workshop and inspiration on the contemporary work of writers and writers-librarians in Serbia and especially in the Republic of Srpska. In this sense, the work gives a review of the literary works of some writers and writers-librarians from the Republic of Srpska (R. Risojević, R. Pavlović, T. Bijelić, M. Stojičić, A. Čvorović, P. Lazarević, Ž. Durđević, S. Bošković , R. Dimitrijević, B. Blagojević) as a basis for some future studies on the interweaving of complex connections and relations between the library, literature, creative process, reading and research.

Keywords: library, literature, Serbian literature, librarianship, inspiration, workshop, writers-librarians, reading, information, material, literary work 